\title{
メタアルデヒド剂トラップを用いたチャコウラナメクジの 生息密度，誘殺率および防除価の推定
}

\author{
田中 寛・萬谷孝治・黒住耐二*・柴尾 学
}

Hiroshi Tanaka, Koji Mantani, Taiji Kurozumi* and Manabu Shibao: Estimation of density, proportion of allurement and efficiency of control in the Valencia slug, Lehmannia valentiana (Férussac) using meta-aldehyde traps

\section{Summary}

We estimated density, proportion of allurement and efficiency of control in the Valencia slug, Lehmannia valentiana (Férussac) by using meta-aldehyde traps. The removal method elucidated the slug density and proportion of allurement in a citrus field to be $25.6 / \mathrm{m}^{2}$ and $38 \%$, respectively. The slug density was larger in order, under tree $>$ on dense grassland $>$ on sparse grassland $>$ bare ground, and the proportion of allurement was larger in order vice versa. Treatment of meta-aldehyde granule of $1 \mathrm{~g} / \mathrm{m}^{2}$ caused $67.5-100 \%$ of slug death, and larger slug density showed lower control efficiency.

$$
\begin{gathered}
\text { 緒 } \quad \overline{\overline{\bar{~}}} \\
\text { チャコウラナメクジ Lehmannia valentiana (Férussac) }
\end{gathered}
$$
（従来はLimax marginatus Müller とされていた）はヨー ロッパ原産で1)，第 2 次大戦後に日本に侵入して1970年 代頃に急増し, 従来生息していたコウラナメクジ（キイ ロナメクジ）Limax flavus L.（本種も移入種の可能性が ある）と置き替わったようであるが，その詳細は不明で ある6)。

本種の英名はV Valencia slug で1), カンキツ, イチジク などの果樹, コマツナ, シュンギク11), キャベツ, ナス などの野菜15), サルビア, マリーゴールド, ペチュニア などの花卉9)でしばしば被害が見られる重要害虫であ る14)。しかし，昼間は遮蔽物の下に潜み，夜間も季節 や天候によって行動が異なるなどのために，発生生態 調査や防除効果判定が容易でなく14), 知見・情報は, 紹介 ${ }^{1,15)}$, 分布 ${ }^{3)}$, 発生状況 ${ }^{3,9,14)}$, 野外での成熟期と寿 命の推定 ${ }^{3)}$, 夜間の行動観察5,7), 忌避・防除効 果 $4,7,8,10,12,14,16)$ 等，断片的なものにとどまる。

そこで, 著者らは, メタアルデヒド剂の誘殺トラップ を用いた簡易な方法により，生息密度，異なる環境条件 下における誘殺率，および防除価を推定したので報告す る。

\section{材料および方法 \\ 1. 生息密度および誘殺率の推定}

試験は1992年 6 月に大阪府立食とみどりの総合技術セ ンター内のウンシュウミカン露地圃場において, 正方形 各 $1 \mathrm{~m}^{2}$ の区画165個 $\left(15 \times 11 \mathrm{~m}, 165 \mathrm{~m}^{2}\right)$ を設置して行 った。ウンシュウミカンの樹齢は20年生, 多品種混植, 栽植距離は $4 \times 4 \mathrm{~m}$ （一部は $4 \times 2 \mathrm{~m} ）$ であり, 各区画の 優占的な環境を第 1 図に示した。なお，5月下旬に除草 剂が散布されたため, 大半の草は枯草となって地面に倒 伏していた。確認されたナメクジは全てチャコウラナメ クジ（千葉県立中央博物館所蔵 CBM-ZM103388; 以下, 混乱を生じないかぎりチャコウラと略す）であった。た だし，外部形態のきわめて類似する隠蔽種が含まれる可 能性は否定できない。

メタアルデヒド剤トラップは, 保土谷化学（株）製六 角錐屋根型ナメクジトラップ（底面直径 $11 \mathrm{~cm}$, 高さ $8 \mathrm{~cm}$ ）に $1 \mathrm{~g}$ のメタアルデヒド粒剂（ナメキール®）を 入れたものとした。これを 6 月 15 日〜 19 日の毎日と 6 月 21 日の計 6 回（調査期間：1 週間), 各区画の中央に夕 方配置して翌朝回収し, 誘殺されたチャコウラを計数し た。

大阪府立食とみどりの総合技術センター・*千葉県立中央博物館 Agricultural, Food and Environmental Sciences Research Center of Osaka Prefecture, Habikino, Osaka 583-0862, Japan; *Natural History Museum and Institute, Chiba, Chuo, Chiba, Chiba 260-8682, Japan 2005年 2 月 14 日受理 


\section{2. 防除価の推定}

試験は2000年 $6 〜 7$ 月に大阪府立食とみどりの総合技 術センター内の上記と同じウンシュウミカン露地戋場に おいて，1区420〜 500 $\mathrm{m}^{2} ， 1$ 区制で行った。確認され たナメクジはやはり全てチャコウラであった。

6 月 15 日夕方，メタアルデヒド水和剤（マイキラー $\left.{ }^{\circledR}\right)$ 200 倍液を $0.4 \mathrm{~L} / \mathrm{m}^{2}$ (動力噴霧機による散布), メタア ルデヒド粒剤（ナメキール®）を $1 \mathrm{~g} / \mathrm{m}^{2}$ （手散布ばらま き）処理し，無処理区も設置した。調査は，処理 3 日前 の 6 月 12 日から処理 27 日後の 7 月 12 日までの間 5 回, 各 区の中央部において $4 \mathrm{~m}$ 間隔で上記と同じメタアルデ ヒド剤トラップを夕方配置して翌朝回収し，誘殺された チャコウラを計数した。

また，2002年 6 月 21 日に大阪府羽曳野市内の民家庭園 2 か所 $\left(\right.$ 各 $\left.100 \mathrm{~m}^{2}\right) ， 2003$ 年 6 月 30 日と 2004年 5 月 27 日 に大阪府立食とみどりの総合技術センター内の上記と同 じウンシュウミカン露地戋場 $\left(\right.$ 各 $\left.200 \mathrm{~m}^{2}\right)$ においてメ タアルデヒド粒剂を $1 \mathrm{~g} / \mathrm{m}^{2}$ （手散布ばらまき）処理し， 处理前と处理 $5 \sim 7$ 日後に同様の調査を行った。防除価 は，100-100×(処理区の処理後トラップあたり誘殺数 $\times$ 無処理区の処理前トラップあたり誘殺数)/(無処理区の 処理後トラップあたり誘殺数 $\times$ 处理区の処理前トラップ あたり誘殺数），により計算した。

\section{結果および考察}

\section{1. 生息密度および誘殺率の推定}

結果は除去法13) により，4つの環境条件（樹下，密

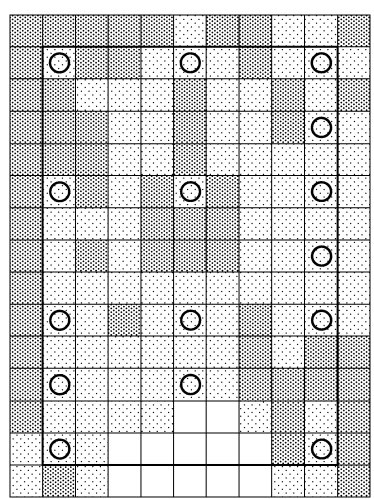

第 1 図トラップ配置区画の環境

1 区画は $1 \mathrm{~m} \times 1 \mathrm{~m}$ 。濃灰色：密な枯草が優占, 淡灰 色: 疎らな枯草が優占, 白色 : 裸地が優占。○：カン キツ樹。太線外部 : 周縁部, 太線内部 : 中央部。

な枯草地, 疎らな枯草地, 裸地）および周縁部と中央部 （第 1 図）を区別して解析した（第 1 表，第 2 図 A〜F） ところ, 裸地を除いて除去法の回帰直線によく適合し $(\mathrm{p}<0.05)$ (第 2 図 $\mathrm{A} \sim \mathrm{C}$ ), 試験地外部からの侵入が少 ないと考えられる中央部の生息密度推定值（推定個体数 $\left./ \mathrm{m}^{2}\right)$ （x 切片）は, 樹下 40.5 , 密な枯草地 31.1 , 疎らな 枯草地21.9, 裸地5.6であり，樹下＞密な枯草地＞疎ら な枯草地＞裸地，の順に生息密度が高かった。この結果 は, チャコウラにとっての生息地の好適さを反映してい ると考えられる。なお，裸地（第 2 図 D）についても， 誘殺数がやや多かった調査最終日の值を除いた場合は除 去法の回帰直線によく適合し $(\mathrm{p}<0.05)$, 生息密度推 定值が4.9であったことから，上記の推定値5.6はほぼ信

第 1 表 チャコウラナメクジの誘殺に関する除去法のパラメータ

\begin{tabular}{|c|c|c|c|c|c|c|c|}
\hline & & 区画数 & 回帰式 & 相関係数\#1 & 推定個体数 $/ \mathrm{m}^{2}$ \#2 & 初回誘殺率（\%)\#3 & 6 回累積誘殺率 $(\%)^{\# 4}$ \\
\hline \multirow[t]{3}{*}{ 樹下 } & 中央部 & 15 & $y=-0.439 x+17.8$ & $0.941 *$ & 40.5 & 29.8 & 88.2 \\
\hline & 周縁部 & - & - & - & - & - & - \\
\hline & 全部 & - & - & - & - & - & - \\
\hline \multirow[t]{3}{*}{ 密な枯草地 } & 中央部 & 32 & $y=-0.519 x+16.2$ & $0.901 *$ & 31.1 & 34.9 & 90.7 \\
\hline & 周縁部 & 27 & $y=-0.339 x+13.2$ & $0.947 *$ & 38.9 & 23.8 & 81.7 \\
\hline & 全部 & 59 & $\mathrm{y}=-0.432 \mathrm{x}+14.8$ & $0.939 *$ & 34.2 & 29.8 & 87.4 \\
\hline \multirow[t]{3}{*}{ 疎らな枯草地 } & 中央部 & 63 & $y=-0.595 x+13.0$ & $0.862 *$ & 21.9 & 41.8 & 94.7 \\
\hline & 周縁部 & 16 & $y=-0.362 x+7.6$ & 0.792 & 21.0 & 30.3 & 84.5 \\
\hline & 全部 & 79 & $\mathrm{y}=-0.550 \mathrm{x}+11.9$ & $0.852^{*}$ & 21.6 & 39.9 & 93.5 \\
\hline \multirow[t]{3}{*}{ 裸地 } & 中央部 & 7 & $y=-1.366 x+7.7$ & 0.441 & 5.6 & 76.3 & 104.2 \\
\hline & 周縁部 & 5 & $y=-1.607 x+6.6$ & 0.327 & 4.1 & 82.9 & 102.4 \\
\hline & 全部 & 12 & $\mathrm{y}=-1.504 \mathrm{x}+7.5$ & 0.416 & 5. 0 & 78.9 & 104.1 \\
\hline \multirow[t]{3}{*}{ 全体 } & 中央部 & 117 & $\mathrm{y}=-0.551 \mathrm{x}+14.1$ & $0.906 *$ & 25.6 & 37.8 & 92.9 \\
\hline & 周縁部 & 48 & $y=-0.362 x+10.3$ & $0.951^{*}$ & 28.6 & 26.6 & 83.9 \\
\hline & 全部 & 165 & $y=-0.492 x+12.9$ & $0.923 *$ & 26.2 & 34.7 & 90.9 \\
\hline
\end{tabular}

\#1*: $\mathrm{p}<0.05$, \#2 生息密度推定值 (回帰式の $\mathrm{x}$ 切片), ${ }^{\# 3} 100 \times\left(\right.$ 初回誘殺数 $\left./ \mathrm{m}^{2}\right) /\left(\right.$ 推定個体数 $\left./ \mathrm{m}^{2}\right)$, ${ }^{\# 4} 100 \times\left(6\right.$ 回累積誘殺数 $\left./ \mathrm{m}^{2}\right) /$ (推定個体数 $/ \mathrm{m}^{2}$ ) 

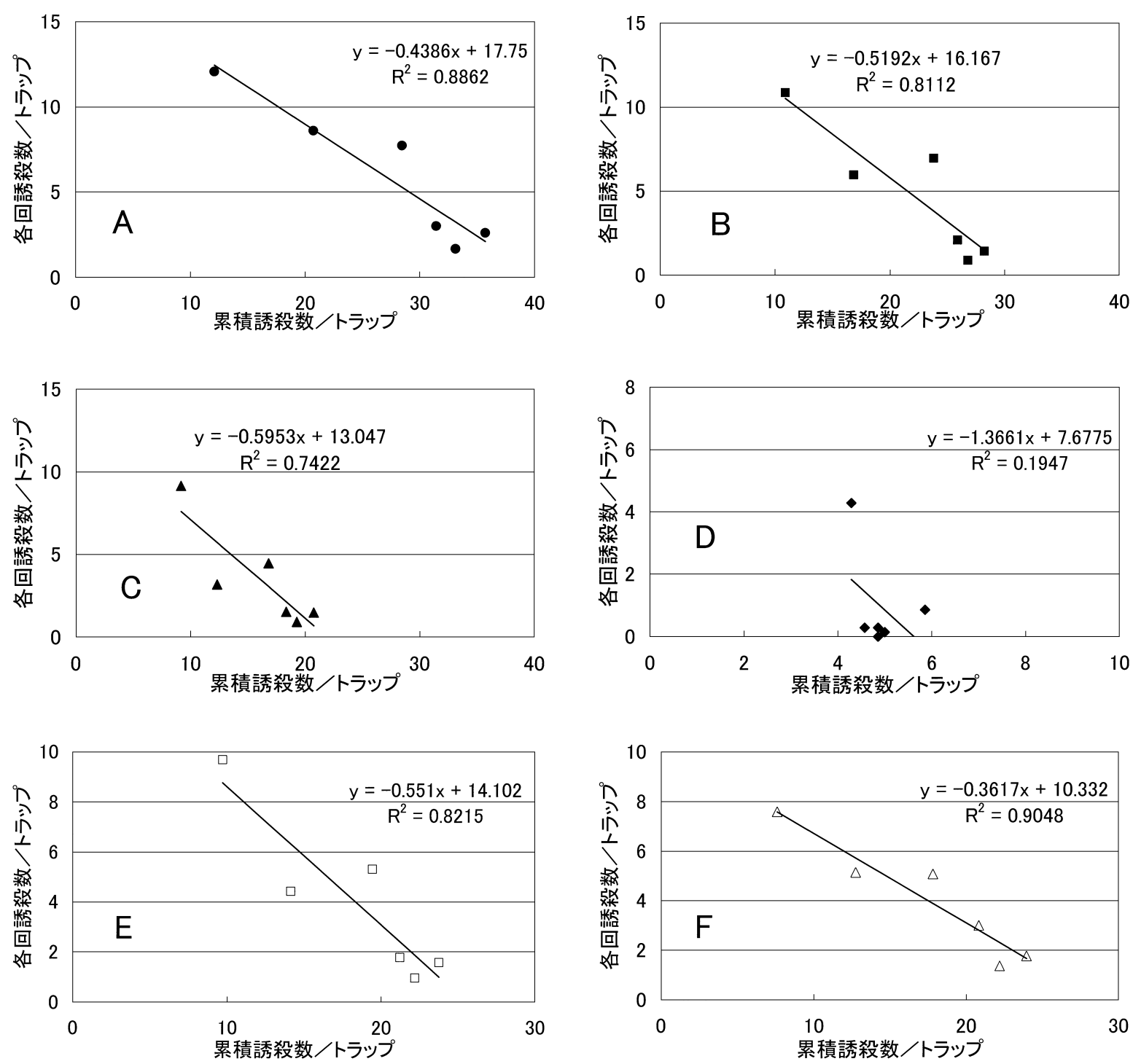

第 2 図＼cjkstart除去法におけるチャコウラナメクジの累積誘殺数と各回誘殺数の関係

$\mathrm{A}$ : 樹下 (中央部) , $\mathrm{B}$ : 密な枯草地 (中央部), $\mathrm{C}$ : 疎らな枯草地 (中央部), $\mathrm{D}:$ 裸地 (中央部), $\mathrm{E}:$ 全体 (中央部), $\mathrm{F}:$ 全 体 (周縁部)。

頼できると考えられる。試験地全体の中央部の生息密度 推定值は $25.6 / \mathrm{m}^{2}$ であった。

周縁部と中央部の生息密度推定值を比較すると，密な 枯草地では周縁部のほうが中央部より高く，疎らな枯草 地では周縁部と中央部はほぼ同等，裸地では中央部のほ うが周縁部より高く，全体では周縁部のほうが中央部よ りやや高い傾向が認められた（第 1 表，第 2 図 $\mathrm{E} \sim \mathrm{F}$ )。 それぞれの周縁部と中央部の生息密度推定值の差は, 試 験地外部との移出入個体数の差とみなすことができるだ ろう。すなわち， 1 週間あたり幅 $1 \mathrm{~m}$ あたり，密な枯 草地では7.8個体の入超，疎らな枯草地では0.9個体の出 超，裸地では 1.5 個体の出超，全体では3.0個体の入超が 生じていると推察される。この值も上記の中央部の生息
密度推定值と同様に, 密な枯草地 > 疎らな枯草地 > 裸地, の順に移入量が大きく, チャコウラにとっての生息地の 好適さを反映していると考えられる。

初回誘殺数と推定個体数の比を初回誘殺率（\%)（= $100 \times\left(\right.$ 初回誘殺数 $\left./ \mathrm{m}^{2}\right) /\left(\right.$ 推定個体数 $\left.\left./ \mathrm{m}^{2}\right)\right)$ とすると, 中央部の值は, 樹下 29.8 , 密な枯草地 34.9 , 疎らな枯草 地 41.8 , 裸地76. 3であり, 生息密度推定值（推定個体数 $\left./ \mathrm{m}^{2}\right)$ とは逆に, 裸地>疎らな枯草地>密な枯草地>樹 下，の順に高かった（第 1 表）。この結果は，不適な生 息地では好適な生息地に比較し，トラップへの誘殺率が 大きいことを示している。また, 試験地全体の中央部の 值は37.8であり，本國場ではメタアルデヒド粒剤 $1 \mathrm{~g} / \mathrm{m}^{2}$ ばらまき処理により, 一晚に $38 \%$ のチャコウラが誘殺 
されると推定される。

6 回累積誘殺数と推定個体数の比を 6 回累積誘殺率 (\%) $\left(=100 \times\left(6\right.\right.$ 回累積誘殺数 $\left./ \mathrm{m}^{2}\right) /\left(\right.$ 推定個体数 $\left.\left./ \mathrm{m}^{2}\right)\right)$ とすると, 中央部の值は, 樹下 88.2 , 密な枯草地 90.7 , 疎らな枯草地 94.7 , 裸地 104.2 であり, 初回誘殺率と同 様, 裸地 $>$ 疎らな枯草地 $>$ 密な枯草地 $>$ 樹下, の順に高 かった。試験地全体の中央部の值は92.9であり，6回の 反復処理（調查期間：1 週間）により93\%のチャコウラ が誘殺されると推察される。なお, 樹下や密な枯草地で は一晚（1 回処理）で10個体以上のチャコウラが誘殺さ れ，メタアルデヒド粒剤はほぼ消費し尽くされるため,

1 回処理により 1 週間で誘殺されるチャコウラの割合は 38\%，ないし38\%と93\%の中間值であると推察される。 なお, 初回誘殺率, 6 回累積誘殺率ともに, 周縁部では 中央部に比較し，各環境とも小さな值を示した。これは 試験地外部からの移入により, 周縁部ではみかけの誘殺 率が小さくなるためと考えられる。

\section{2. 防除価の推定}

メタアルデヒド水和剂および粒剂処理により，処理 5 日後には，無処理区でトラップあたり誘殺数が倍増した にもかかわらず，薬剤処理区ではトラップあたり誘殺数 が大きく減少した（第 3 図）。処理 5 日後の防除価は,

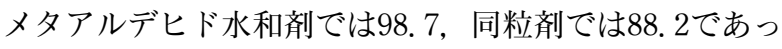
た。薬剤処理区のメタアルデヒド剤トラップは他区との 境界線から $8 \mathrm{~m}$ 以上離れた地点に配置したため, 処理 後 1 週間におけるトラップ地点付近への移入個体数はき わめて少ないと推察される。その後, 薬剂処理区と無処 理区の誘殺数の差は漸減し, 両区の誘殺数は処理27日後 にはほぼ同等になった。

2000〜2004年の合計 5 回のメタアルデヒド粒剂処理 （ $1 \mathrm{~g} / \mathrm{m}^{2}$ 手散布ばらまき）による処理 $5 \sim 7$ 日後の防除 価を処理前のトラップあたり誘殺数と比較して第 4 困に 示した。処理前のトラップあたり誘殺数が10以下では防 除価は100であるのに対し，同誘殺数が10を超えて増加 するにつれて, 防除価が減少する傾向が認められる。こ れは，処理前のトラップあたり誘殺数が10を超える生息 密度の場合は，散布されたメタアルデヒド粒剂が短期間 に消費し尽くされ，誘殺できなかったチャコウラが残存 することを示唆している。

本研究により, メタアルデヒド剤トラップへの誘殺数 にもとづいて, チャコウラの生息密度, 誘殺率, 防除価 等を推定できることが明らかになった。しかし，依然と して, 日本における本種の行動，生態については不明な 点が多すぎる。本種について大阪府における誘殺消長が 示されているが14), これが生息密度の消長とどのような

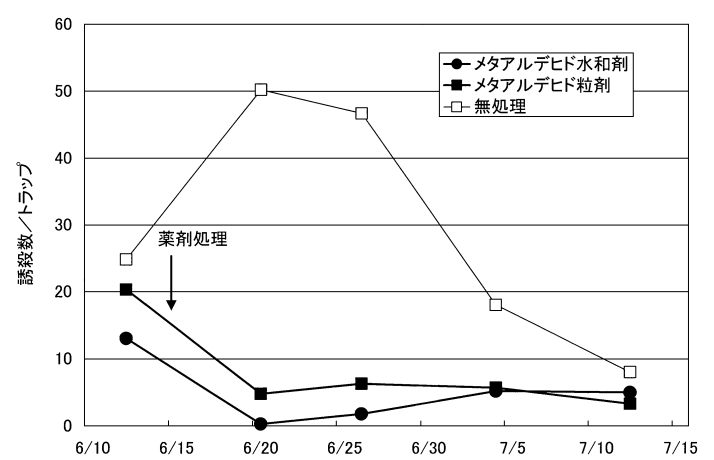

第 3 図 メタアルデヒド剤処理にともなうチャコウラナメクジ 誘殺数の推移

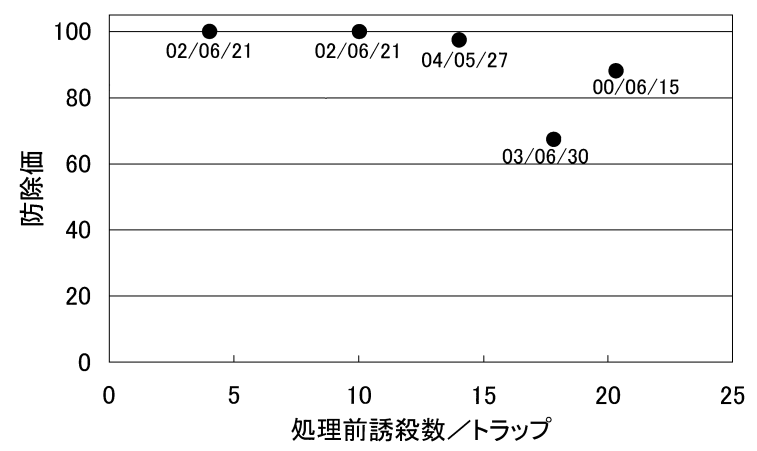

第 4 図 チャコウラナメクジの処理前のトラップあたり誘殺数 とメタアルデヒド粒剤による防除価の関係 図中の数字は処理日（年/月/日）を示す。

関係にあるか不明である。したがって，本研究において 示された誘殺率, 防除価とトラップあたり誘殺数の関係 も季節や天候によって大きく異なる可能性があり, 今後 異なる季節で同様の調査を行って検討する必要がある。

効率的な防除にあたって, 実験室と野外における生育 期間, 産卵数, 寿命などの詳細な情報, 野外での移動分 散の情報も, 解明は容易ではないが, 不可欠である。こ れらも併せ, 基礎的・応用的な研究が多数実施されるこ とが望まれる。

\section{摘 要}

メタアルデヒド粒剤のトラップを用いてチャコウラナ メクジの誘殺数を調査し, 生息密度, さまざまな環境に おける誘殺率，および防除価を推定した。除去法により 解析した結果, カンキツ園における生息密度は $25.6 / \mathrm{m}^{2}$, トラップあたり一晚あたりの誘殺率は $38 \%$ と推定され た。環境別の生息密度は, 樹下>密な枯草地>疎らな枯 草地 > 裸地, の順に高く, 誘殺率は逆に, 裸地>疎らな 枯草地 $>$ 密な枯草地 $>$ 樹下, の順に高かった。メタアル デヒド粒剂 $1 \mathrm{~g} / \mathrm{m}^{2}$ 処理による防除価は67.5〜100であ り, 生息密度が高いほど防除価が低い傾向が認められた。 


\section{引用文献}

1) Baker, G. M. (1999) Naturalised terrestrial Stylommatophora (Mollusca: Gastropoda). Lincoln (Canterbury, New Zealand). pp. 79-81.

2) 藤田 卓 (1959) 遺伝 13(6) : 15-18.

3 ) Kano, Y. et al. (2001) Yuriyagai, J. Malacozool. Ass. Yamaguchi 8(1): 1-13.

4）久保田豊ら（2002）関西病虫研報 $44: 51-52$.

5）國本佳範（1998）関西病虫研報 $40: 51-53$.

6）黒住耐二（2002）外来種ハンドブック（日本生態学会編）. 地人書館, p. 164.
7）松村達夫（1973）動物と自然 3(11）：18-21.

8）奥谷禎一・吉岡英二（1983）関西病虫研報 $25: 1-3$.

9）柴尾 学ら（2001）関西病虫研報 $43: 33-34$.

10）柴尾 学ら（2002）関西病虫研報 $44: 49-50$.

11）柴尾 学ら (2004) 関西病虫研報 $46: 33-38$.

12）柴田岳彦ら（1991）関西病虫研報 $33: 137$.

13) Southwood, T. R. E. (1978) Ecological method. 2nd ed. John Wiley \& Sons. pp. 230-236.

14）田中 寛・柴尾 学（2001）今月の農業 45(9)：58-61.

15）田中 寛 - 柴尾 学（2002）環境管理技術 20:134-142.

16）田中 宽ら（2001）大阪農技七研報 $37: 23-26$. 